\title{
Weryfikacja wersji zabójstwa w przypadkach zaginięcia człowieka
}

\author{
RYSZARD JAWORSKI \\ ORCID: 0000-0002-0906-1569 \\ Katedra Bezpieczeństwa Wewnętrznego \\ Wyższej Szkoły Prawa we Wrocławiu
}

\section{Weryfikacja wersji zabójstwa w przypadkach zaginięcia człowieka}

Czynności w przypadkach zaginięcia człowieka prowadzone są na podstawie art. 14 ust. 3 ustawy z dnia 6 kwietnia 1990 roku o Policji ${ }^{1}$. Działania te, zgodnie z ustawą, były w znacznej części niejawne. Policja nie była obowiązana do informowania o rodzaju działań poszukiwawczych, a jedynie o ich wyniku. Status prawny osób zainteresowanych odnalezieniem zaginionego był niejasny, nawet jeśli byli to członkowie jego rodziny. Na tym tle dochodziło do konfliktów między rodziną zaginionego a policją: rodzina zarzucała funkcjonariuszom bezczynność, ci zaś mogli ujawnić tylko niektóre działania. Zaginięcie człowieka, jeśli dotyczy osoby dorosłej, nie jest podstawą do wszczęcia postępowania karnego, nie ma więc osób pokrzywdzonych, którym przysługuje prawo

1 ,W granicach swych zadań Policja wykonuje czynności: operacyjno-rozpoznawcze, dochodzeniowo-śledcze i administracyjno-porządkowe w celu: [...] 3) poszukiwania osób, które na skutek wystąpienia zdarzenia uniemożliwiającego ustalenie miejsca ich pobytu należy odnaleźć w celu zapewnienia ochrony ich życia, zdrowia lub wolności, zwanych dalej »osobami zaginionymi«" - ustawa z dnia 6 kwietnia 1990 roku o Policji, Dz.U. 2019 poz. 2020, art. 14.1. 
do uczestnictwa w niektórych czynnościach i wobec których istniałby obowiązek powiadomienia o wyniku postępowania ${ }^{2}$.

Ocenę zasadności zarzutów znali wyłącznie policjanci, a ich przełożony mógł je ocenić na podstawie dokumentacji i znajomości ich aktywności, a — jak wiadomo — dokumentację można wytworzyć, nie ruszając się zza biurka. Konflikt ten nie był ignorowany przez policję, czego wyrazem są częste nowelizacje Zarządzenia Komendanta Głównego Policji w sprawie poszukiwania zaginionych ${ }^{3}$. Dostrzega się w nich nie tylko dążenie do sprecyzowania definicji i przebiegu czynności poszukiwawczych, ale też ich dokumentowania oraz kontrolowania przez przełożonych, co — w założeniu — powinno ułatwić osobom zainteresowanym ocenę pracy funkcjonariuszy.

Okolicznością komplikująca relacje policji z rodziną zaginionego o czym się nie mówi — były także przyjmowane niekiedy wersje zdarzenia zakładające dokonanie zabójstwa przez kogoś z bliskich lub przyczynienie się do samobójstwa (presja psychiczna, mobbing). Działania weryfikujące takie wersje — z oczywistych względów — nie były i nie są ujawniane osobom, które mogły dopuścić się tych zachowań. Tego rodzaju hipotezy były jeszcze częściej wysuwane przez lokalną społeczność (plotki) lub dalszą rodzinę zaginionego, co stwarzało dla najbliższych problemy emocjonalne, a przeważnie było nieuzasadnione. Nieuchronne stawało się ujawnienie takich wersji i podjęcie prób ich zweryfikowania. Wybór metody sprawdzania połączony był z wątpliwościami natury procesowej: jeśli przesłuchanie, to najpierw należy wszcząć postępowanie karne, ale co powinno być podstawą wszczęcia postępowania - zabójstwo, uprowadzenie, nakłanianie do samobójstwa?

2 Wszczęcie postępowania jest możliwe, gdy ustalone zostaną fakty uprawdopodobniające, że przyczyną zaginięcia jest przestępstwo (uprowadzenie dla okupu itd.). W przypadku zaginięcia dziecka wszczęcie postępowania może nastąpić szybciej i będzie ono prowadzone przeciwko opiekunom dziecka (zarzut niedopełnienia obowiązku opieki).

3 Aktualnie obowiązuje Zarządzenie nr 48 Komendanta Głównego Policji z dnia 28 czerwca 2018 roku w sprawie prowadzenia przez Policję poszukiwania osoby zaginionej oraz postępowania w przypadku ujawnienia osoby o nieustalonej tożsamości lub znalezienia nieznanych zwłok oraz szczątków ludzkich. Poprzednio: Zarządzenie nr 352 Komendanta Głównego Policji z dnia 16 lipca 2003 roku, Zarządzenie KGP nr 124 z 4 czerwca 2012 roku. 
Jednym ze sposobów weryfikacji wspomnianych wersji było i jest badanie poligraficzne osób pomawianych o przyczynienie się do „zniknięcia" człowieka. Stosowane są w tym celu dwie metody badawcze (testy). Pierwsza z nich to tzw. testy pytań porównawczych (CQT - Control Question Test; dawniej: testy pytań kontrolnych), a druga to testy wiedzy ukrywanej (CIT - Concealed Information Test) w wersji testów poszukiwawczych (inna nazwa: testy z nieznanym rozwiązaniem).

W pierwszej grupie metod zadawane są trzy rodzaje pytań: neutralne, relewantne i porównawcze (kontrolne). Pytania neutralne dotyczą faktów oczywistych, a ich celem jest rejestrowanie parametrów fizjologicznych. Pytania relewantne, których jest trzy lub cztery, dotyczą roli badanej osoby w zdarzeniu (Czy to pan ukrył ciało?), a pytania porównawcze (dwa lub trzy) dotyczą innych, moralnie nagannych zachowań badanej osoby (Czy oszukał pan urzędnika?). Wersję o udziale badanego w przestępstwie należy odrzucić, gdy zmiany fizjologiczne po pytaniach porównawczych są większe niż po pytaniach relewantnych. Przykłady pytań zadanych w rzeczywistych sprawach podane są $\mathrm{w}$ dalszej części publikacji.

Techniki CQT wzbudzają u niektórych wątpliwości odnośnie do ich założeń, a tym samym trafności, ponieważ — zdaniem sceptyków — silne emocje po pytaniach relewantnych ( $\mathrm{tj}$. dotyczących wyjaśnianego zdarzenia) wystąpić mogą również u człowieka niesłusznie posądzanego (emocje niewinnego). Zdaniem krytyków trudno opracować pytania kontrolne równoważne emocjonalnie pytaniom relewantnym. Wątpliwości te są szczególnie aktualne, gdy badamy kogoś z rodziny zaginionego. Niektóre pytania (Czy zabiłeś X?) mogą spowodować u tych badanych nadmierne emocje, czego następstwem byłyby znaczne zmiany w parametrach fizjologicznych ${ }^{4}$. Można byłoby zatem sądzić, że w przypadkach zaginięcia człowieka trafność tego testu może być niższa niż w sprawach o kradzież czy rozbój. $Z$ tego powodu w sprawach zaginięcia człowieka wskazane jest uzupełnienie metody badawczej o takie testy, które mogą podnieść trafność badania poligraficznego, a są nimi testy zaliczane do drugiej grupy.

Druga grupa to testy wiedzy ukrywanej (CIT) w wersji testów poszukiwawczych, określane w języku angielskim jako Searching Peak of Tension

${ }^{4}$ Rozwiązaniem tego problem jest test wyboru pytania kontrolnego. Por. R. Jaworski, Personalization and calibration of the control question in the control question test, „Journal of Forensic Identification” 61, 2011, nr 5. 
Tests (SPOT). Testy takie stosowane są w ekspertyzie psychofizjologicznej w USA od roku $1929^{5}$. W roku 1929 L. Keller zastosował kilka testów tego typu (w tym testy z mapą) w sprawie zabójstwa J.E. Bassetta ${ }^{6}$. Spektakularne efekty zastosowania testów SPOT do wykrycia i udowodnienia zabójstw w przypadkach kwalifikowanych początkowo jako zaginięcie osób opisał Owen M. Wilkerson ${ }^{7}$. Jeden z tych przypadków dotyczył badania podejrzanego o uprowadzenie dwóch kobiet w 1977 roku. Podczas badania użyto kilku testów SPOT. W pierwszym teście wymieniane były nazwy kilku powiatów. Badany reagował na nazwę jednego z nich. Następny test polegał na okazywaniu mapy tego powiatu. Badany wyraźnie reagował na jeden z sektorów. Ten fragment terenu przeszukano i znaleziono ciała kobiet. Sąd skazał podejrzanego na karę śmierci.

Testy SPOT stosowane są także od dawna w Japonii w przypadkach zaginięcia człowieka. Jak pisze Makoto Nakayama:

Jeśli niemożliwe jest sformułowanie pytań krytycznych, SPOT jest bardzo często przeprowadzaną metodą w Japonii. Kiedy jakaś osoba nagle znika, a motywacje na tle samobójczym bądź ucieczki zostają wykluczone, policja musi rozważyć opcję zabójstwa. Testy dotyczą takich kwestii jak: data, miejsce, sposób popełnienia morderstwa, usunięcie ciała ${ }^{8}$.

Kilka przykładów zastosowania tych testów w przypadku zaginięcia człowieka (wraz z zapisami testów) przedstawili autorzy litewscy. Jeden z podejrzanych przyznał się do zabójstwa i wskazał miejsce ukrycia zwłok ${ }^{9}$.

Mimo częstego stosowania SPOT przez ponad 80 lat w różnych krajach liczba publikacji na ten temat (w zestawieniu z artykułami na temat innych technik) jest niewielka. Opisywane są pojedyncze przypadki. Wynika to zapewne z tego, że eksperci zajęci są bieżącą pracą.

5 J.A. Matte, Forensic Psychophysiology Using the Polygraph. Scientific Truth Verification - Lie Detection, Willamsville-New York 1996, s. 497.

6 A. Johnston, Saga o Leonardzie Keelerze, „Saturday Evening Post” kwiecień 1944, cyt. za: Academy Lectures on Lie-Detection, t. 2, Springfield 1958, s. 9-11.

7 O.M. Wilkerson, The peak of tension tests utilized in the Ashmore kidnapping, „Polygraph” 7, 1978, nr 1.

8 M. Nakayama, Practical Use of the Concealed Information Test for Criminal Investigation in Japan, [w:] Handbook of Polygraph Testing, red. M. Kleiner, London 2002, s. 58 .

9 V. Saldziunas, A. Kovalenko, The event knowledge test (ekt) in polygraph examination (in case murder), „European Polygraph” 2, 2008, nr 2 (4). 
Istotną trudność mogą sprawiać przypadki badań poligraficznych członków rodziny zaginionego, gdy istnieje hipoteza dokonania zabójstwa przez te osoby. Hipoteza może być nietrafna, a członkowie rodziny mogą być oburzeni podejrzeniem i odmówić udziału w badaniu. Propozycja zastosowania SPOT może pogłębić negatywny stosunek do badania (rodzina nie chce zaakceptować faktu śmierci i jest przekonana, że zaginiony żyje). W tych sytuacjach test SPOT może dotyczyć części odzieży lub przedmiotu, jaki zaginiony miał przy sobie.

Okolicznością, która - mimo tych obiekcji — może skłonić osoby bliskie do zgody na badania, są pomówienia ze strony otoczenia (najczęściej na wsi) o zabójstwo albo o działania (mobbing), które skłoniły zaginionego do oddalenia się i popełnienia samobójstwa. Niekiedy presja otoczenia nie ogranicza się do okazywania objawów niechęci, ale — jak podano poniżej — przybiera formę gróźb (pobicie, podpalenie domu).

\section{Przypadek 1}

Zdarzenie z roku 1979 polegało na zaginięciu starszego mężczyzny na terenie wiejskim. Mieszkańcy wioski był przekonani, że było to zabójstwo dokonane przez kolegę „zaginionego”: krytycznego wieczoru mężczyźni pili razem alkohol w mieszkaniu posądzanego, a następnego dnia ten rolnik wyjeżdżał wozem konnym na swoje pole. Sąsiedzi interpretowali te fakty następująco: mężczyźni upili się, pokłócili, pobili, jeden uderzył drugiego za mocno, zabił go, a następnego dnia „sprawca” wywiózł i zakopał ciało w lesie lub w polu albo wrzucił do bagna. Kolega zaginionego nie miał motywu zabójstwa, przeciwnie — razem służyli w wojsku podczas wojny. Nie było świadków, gdyż obaj mężczyźni mieszkali samotnie (byli wdowcami). Mieszkańcy wioski byli tak pewni słuszności podejrzeń, że grozili temu mężczyźnie linczem. Te groźby oceniał on jako realne i domagał się od policji ochrony poprzez zamknięcie go w areszcie. Oprócz pomówień nie było żadnych podstaw do przedstawienia zarzutu i aresztowania go. Przygotowałem test CQT i dwa testy SPOT. Pierwszy SPOT dotyczył daty, a właściwie dnia ostatniego spotkania z zaginionym, drugi zaś sposobu ukrycia zwłok. Testy wykluczyły przyczynienie się mężczyzny do śmierci kolegi. Wynik badania potwierdził się po kilku dniach: zwłoki znaleziono w rzece, a autopsja wykazała, że człowiek ten był żywy, wpadając do wody. Przyczy- 
ną śmierci było utonięcie. Na zwłokach nie było żadnych obrażeń mogących spowodować śmierć ani śladów pobicia, a we krwi zmarłego stwierdzono wysokie stężenie alkoholu. Prokurator umorzył sprawę.

\section{Przypadek 2}

Sprawą, w której użyto takich testów - a warto ją przytoczyć, gdyż mimo braku ciała ofiary nastąpiło skazanie za zabójstwo — jest zaginięcie dziewięcioletniej Beaty K. w marcu 1979 roku w Oławie ${ }^{10}$. Czynności poszukiwawcze podjęto tego samego dnia, przy użyciu m.in. psów tropiących. Psy doprowadziły nad Odrę w pobliże oczyszczalni ścieków. Znaleziono tam na śniegu ślady butów dziecka i osoby dorosłej, wstążkę do włosów i guzik pochodzący z płaszcza zaginionej. Dziecka nie znaleziono. Tego samego dnia, dzięki rozpytaniu koleżanek szkolnych zaginionej, ustalono rysopis możliwego sprawcy uprowadzenia. Mężczyzna, zatrzymany następnego dnia, przyznał się do zgwałcenia dziewczynki i wepchnięcia jej do rzeki. Podczas wizji lokalnej przedstawił przebieg zdarzenia, zgadzało się to z rodzajem i usytuowaniem śladów. Ciała dziecka poszukiwano nadal, nie tylko w rzece, ale i na jej brzegach. Nie dały one efektu. Prokurator wydał postanowienie o przeprowadzeniu ekspertyzy poligraficznej, gdyż podejrzany zmienił wyjaśnienia — twierdził, że dziecko samo wpadło do Odry (próbowano ustalić, czy podejrzany nie ukrył ciała w innym miejscu).

W jednym z testów były wymieniane różne sposoby spowodowania śmierci, różne miejsca ukrycia ciała, różne miejsca, w których mogła nastąpić śmierć dziecka (podejrzany podawał, że wpadła do rzeki, natomiast mogła stracić życie podczas gwałtu (wstrząs psychiczny, uduszenie)). Wyniki nie były jednoznaczne ${ }^{11}$.

Z powodu zmiany wyjaśnień podejrzanego postanowiono też sprawdzić, czy sprawca zwłok nie zakopał. Powołano w tym celu biegłego z zakresu termowizji. Po oględzinach terenu biegły stwierdził, że zastosowanie tej metody jest niecelowe, gdyż teren ma bardzo niejednorodną

10 Prokuratura powiatowa w Oławie, sygnatura akt Ds. 70/79.

11 R. Jaworski, Poligraficzny test ,wydobywczy” przy poszukiwaniu ciała ofiary zabójstwa, „Wrocławskie Studia Sądowe” 4, 2012, nr 3, s. 50-59. 
strukturę (liczne wcześniejsze wykopy). Sąd wojewódzki skazał oskarżonego za zabójstwa na karę dwudziestu pięciu lat pozbawienia wolności ${ }^{12}$. Ponieważ skazanie nastąpiło mimo braku ciała ofiary, interesujące jest uzasadnienie, jakie w kwestii tego faktu dowodowego przyjął sąd:

Zwłok denatki nie odnaleziono, ale jak wynika z danych zawartych na k. 357-360 — rzeka Odra niechętnie oddaje swe ofiary. Akt zgonu Beaty K. nie został jeszcze sporządzony. Nie można jednak łudzić się, że jakimś trafem została ona uratowana i pewnego dnia zjawi się cała i żywa. Przeprowadzone wszechstronne czynności poszukiwawcze, z ogłoszeniami prasowymi, komunikatami i zawiadomieniami skierowanymi do placówek służby zdrowia, przekreślają wszelkie nadzieje, że Beata K. znajduje się jeszcze inter vivos. W krajach anglosaskich z procedurą karną hołdującą zasadzie prawdy formalnej „,koroner” nie wszczyna postępowania o umyślne zabójstwo, gdy nie ma zwłok ofiary i brak jest bezpośrednich dowodów zbrodni. W naszym kraju podstawowym zadaniem procesu karnego jest wykrycie prawdy materialnej. Stąd omawiana wyżej sytuacja nie stanowi ujemnej przesłanki procesowej, uniemożliwiającej ściganie R.K. o czyn z art. 148 § 1 k.k.

Sąd Najwyższy utrzymał w mocy ten wyrok ${ }^{13}$. Nie rozważał znaczenia braku ciała denatki, z czego należy wnioskować o aprobacie dla stanowiska sądu wojewódzkiego w tej kwestii.

\section{Przypadek 3}

W połowie marca 1986 roku zgłoszono zaginięcie sześćdziesięcioletniego mężczyzny z jednej z lubuskich wsi. Jedną z przyczyn zaginięcia mogło być zabójstwo ${ }^{14}$. Poszlaki obciążały żonę i syna zaginionego, gdyż nie zawiadomili oni o zdarzeniu, a dokonała tego, i to dopiero po trzech dniach od zaginięcia, oddzielnie mieszkająca córka. W mieszkaniu znaleziono plamy krwi na ścianach, meblach i odzieży. Motyw zabójstwa był prawdopodobny, gdyż mężczyzna ten od wielu lat nadużywał alkoholu, awanturował się i groził zabójstwem członkom rodziny. Od dłuższego czasu zajmował on w budynku osobne pomieszczenia, a kontakty z żoną i synem były ograniczone. Żona i syn mężczyzny twierdzili, że właśnie

12 Sąd wojewódzki we Wrocławiu, sygnatura akt III K 104/79. Mimo względnie młodego wieku (27 lat) oskarżony był już parokrotnie karany za inne przestępstwa.

13 Sygnatura akt Sądu Najwyższego II Kr 192/80.

14 Por. R. Jaworski, Praktyczne zastosowanie badań poligraficznych i ich ocena etyczna, „Problemy Praworządności” 1989, nr 2, s. 43. Prokuratura rejonowa w Żarach 1978 Ds. $490 / 86$.

Nowa Kodyfikacja Prawa Karnego 56, 2020

(C) for this edition by CNS 
dlatego nie spostrzegli zaginięcia, a ponadto byli przekonani, iż przebywa on w pracy. Tłumaczenie to było prawdopodobne, gdyż zaginiony pracował jako stróż na różne zmiany, a w pracy również się upijał.

Dwa tygodnie po zaginięciu przeprowadzono badania poligraficzne syna i żony zaginionego. Wszystkie osoby były badane przy użyciu testu pytań porównawczych (kontrolnych) oraz testu poszukiwawczego, który dotyczył miejsca ukrycia ciała (zawierał on osiem możliwości). U osób badanych występowały początkowo objawy emocji (tętno, oddech), ale ustąpiły one podczas kolejnych zapisów. U żadnej z nich nie było reakcji na alternatywy testu poszukiwawczego. Hipotezę o przyczynieniu się żony i syna zaginionego można było odrzucić, chociaż poprzednio wydawała się ona prawie pewna.

Po dalszych dwóch tygodniach, gdy nastąpiła odwilż, zwłoki zaginionego znaleziono w rzece. Sekcja zwłok nie wykazała obrażeń zewnętrznych. Przyczyną śmierci było utonięcie, we krwi stwierdzono 3,31 promille alkoholu. Dalsze czynności na tyle uprawdopodobniły przypadkowe zatonięcie, że w końcu czerwca 1986 roku umorzono postępowanie z powodu braku cech przestępstwa. Nie wyjaśniono pochodzenia plam krwi w mieszkaniu.

\section{Przypadek 4}

Kolejny przypadek dotyczy zastosowania ekspertyzy poligraficznej po znalezieniu ciała, gdy fakt zabójstwa był ewidentny. Kazus ten ilustruje jednak dobitnie podejście policji do takich zdarzeń i jego skutki w postaci niewykrycia zabójcy. Badania przeprowadziłem w 1996 roku, po upływie roku od „zaginięcia” mężczyzny (sześć miesięcy po „zniknięciu" znaleziono ciało) ${ }^{15}$. Zaginiony prowadził firmę. Krytycznego dnia był w domu sam. Po powrocie do domu żona nie zastała męża. Zobaczyła w kuchni plamy krwi, wezwała policję, policjanci kazali jej posprzątać mieszkanie i wytrzeć krew. Następnego dnia znalazła plamy krwi w garażu. Wtedy policja wykazała większe zainteresowanie, przyjęto zgłoszenie o zaginięciu. Podstawowa wersja policji zakładała, że zaginięcie jest pozorowane, człowiek ten miał bowiem liczne długi (prawdopodobnie uciekł przed wierzycielami), a żona współdziała z mężem. Po sześciu

15 Prokuratura Rejonowa w Jeleniej Górze, sygnatura akt 1 Ds. 81/94/S. 
miesiącach od zaginięcia znaleziono zwłoki. Wersja ucieczki okazała się błędna - było to zabójstwo. Przyjęto wersję o sprawcy zabójstwa: mógł to być syn zabitego - miał motyw zabójstwa, a nie miał wiarygodnego alibi na krytyczny dzień. Okoliczności zdarzenia wskazywały, że syn denata musiałby współdziałać $\mathrm{z}$ dwoma rówieśnikami. Oni również nie mieli alibi, a każdy $\mathrm{z}$ nich miał $\mathrm{z}$ denatem poważny konflikt i mogło im zależeć na śmierci tego człowieka. Zapisy młodych mężczyzn, którzy mieliby współdziałać przy zabójstwie, były bardzo zbliżone: umiarkowane pobudzenie ogólne, przewaga reakcji na pytania kontrolne nad pytaniami relewantnymi. Stwarzało to podstawę do łącznej analizy wyników badań całej trójki, gdyż wyniki te uzupełniały się wzajemnie ${ }^{16}$. Wykluczono wersję ich udziału w zabójstwie.

Sprawcy zabójstwa nie wykryto, a zasadniczą przyczyną było kurczowe trzymanie się wersji o pozoracji zaginięcia. Tymczasem tę wersję można było zweryfikować już po paru dniach, wykonując badanie poligraficzne żony (Czy wie, gdzie jest mąż?). Jest zaś prawdopodobne, że uprowadzony podjął próbę obrony i zranił napastnika (duża ilość krwi w dwóch miejscach). Rażące zaniedbania policji uniemożliwiły wykrycie zabójcy.

\section{Przypadek 5}

Zdarzenie z lata 1991 roku polegało na zaginięciu piętnastoletniej dziewczyny. Badanych było kilka osób ${ }^{17}$. Podejrzenia koncentrowały się wokół matki zaginionej dziewczyny, wobec której istniały nawet dwie hipotezy:

1) Razem z kochankiem zabiła swą córkę, ukryła jej ciało oraz rower (dziewczyna wyjechała $\mathrm{z}$ domu na rowerze, nie znaleziono roweru).

2) Razem z mężem wyraziła zgodę na nieformalną adopcję córki przez małżeństwo zamieszkałe za granicą.

Drugą osobą był ojciec zaginionej (hipoteza: zgodził się na adopcję), a trzecią — domniemany kochanek matki zaginionego dziecka (hipoteza:

16 Dokładny opis przypadku i zapisy z badań zamieszczone są w monografii: R. Jaworski, Multi-subject Polygraph Examination, Wrocław 2008.

17 R. Jaworski, Poligraf jako narzędzie weryfikacji wersji zabójstwa, Wrocław 2018, s. $145-173$. 
współdziałanie co najmniej w ukryciu zwłok i roweru). Czwartą osobą był sąsiad rodziców - mógł zgwałcić i zabić dziewczynę.

Badania przeprowadziłem w roku 1992, po dziewięciu miesiącach od zaginięcia dziewczyny, przed znalezieniem zwłok. W pytaniach relewantnych ujęta była tylko wersja zabójstwa.

Matka zaginionej zgodziła się na badanie, gdyż czuła się zaszczuta przez otoczenie, była wyczerpana podejrzeniami i widziała możliwość oczyszczenia się w ten sposób. Kobieta po zapoznaniu z pytaniami testu miała pełną świadomość przyjętej wobec niej hipotezy o zabójstwie własnej córki. Objawy emocji wystąpiły u niej na początku (drżenie rąk i zmiany w barwie głosu), ale zanikły w trakcie dalszych etapów badania. Utrwalone parametry fizjologiczne również wskazywały na przeciętne pobudzenie tej kobiety tętno wynosiło od dziewięćdziesięciu do stu cykli na minutę.

Pytania relewantne testu:

3. Czy wie pani, kto pozbawił życia M.?

5. Czy to pani pozbawiła życia M.?

9. Czy wie pani, gdzie jest ciało M.?

Pytania kontrolne: 6 i 10.

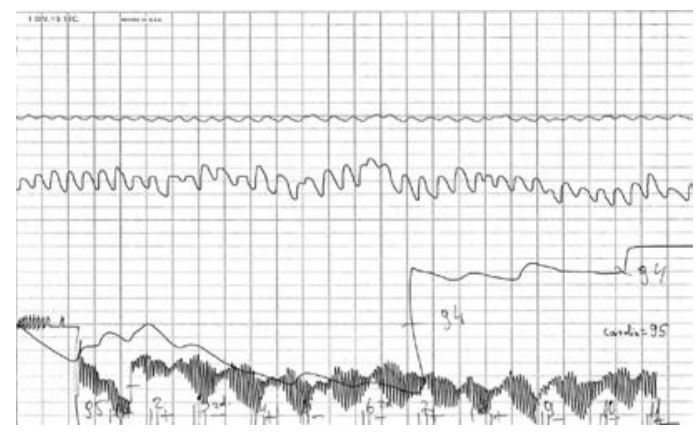

Il. 1. Jeden z zapisów testu pytań kontrolnych dokonanych z matką zaginionej.

Na dole zapisu podane są numery pytań.

Źródło: materiały własne autora.

Proporcje reakcji między pytaniami relewantnymi (nr 3, 5, 8, 9) a kontrolnymi (nr 6 i 10) były typowe dla osób, które nie ukrywają swej prawdziwej relacji do faktów, jakich dotyczą pytania relewantne. 


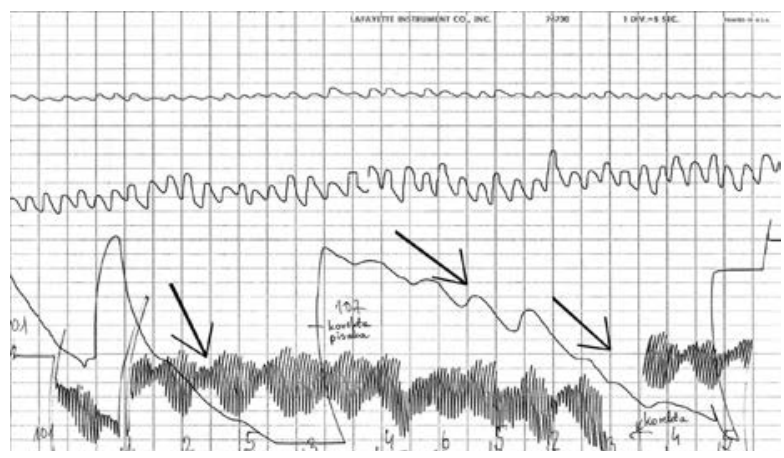

Il. 2. Jeden z zapisów testów poszukiwawczych z badań matki zaginionej dziewczyny (miejsce ukrycia roweru). Strzałki wskazują na cechę świadczącą o obniżaniu się u badanej napięcia emocjonalnego.

Źródło: materiały własne autora.

Wykonałem ponadto kilka testów poszukiwawczych (SPOT). Dotyczyły one: miejsca ukrycia ciała, miejsca ukrycia roweru, osoby sprawcy (w tym teście były nazwiska kilku mieszkańców wioski, w tym także jej własne i domniemanego kochanka). W żadnym z tych testów nie było reakcji na jakąś alternatywę; przeciwnie — następował stały i znaczny spadek ogólnej aktywacji (GSR — Galvanic Skin Response). Świadczyło to jednoznacznie, że kobieta ta nie odczuwa zagrożenia tematyką tych testów, a z tego należy wnioskować, że nie zna i nie ukrywa szczegółów dotyczących ukrycia ciała, ukrycia roweru lub osoby sprawcy.

Podczas badań domniemanego kochanka tej kobiety (hipoteza współsprawstwa w zabójstwie, a co najmniej pomoc w ukryciu ciała) stosowałem takie same testy jak poprzednio. W trzech zapisach testu według techniki Reida reakcje na pytania relewantne nie występowały, a były reakcje na pytania kontrolne. Zapisy testów poszukiwawczych były podobne jak u matki zaginionej. Opinia końcowa: należy wykluczyć wersję o przyczynieniu się tego człowieka do zaginięcia dziewczyny lub ukrycia jej ciała. W odniesieniu do ojca zaginionej był użyty tylko test pytań kontrolnych, a utrwalone parametry wykluczały hipotezę ujętą w pytaniach relewantnych. Zupełnie inne i zaskakujące były reakcje sąsiada rodziców: wykazywał duże emocje w teście według techniki Reida, nasilające się podczas powtarzania testu, a równocześnie brak było reakcji na pytanie „Czy to pan pozbawił życia dziewczynę?”. W zapi- 
sach testu dotyczącego ukrycia ciała parametry fizjologiczne świadczyły o narastającym strachu. Mężczyzna odmówił dalszego udziału w badaniu. Analiza zapisów prowadziła do wniosku, że hipotezę o sprawstwie zabójstwa należy wykluczyć, ale człowiek ten zna fakty, które dotyczą zdarzenia. Człowiek ten powinien być szczegółowo przesłuchany.

Wyniki badań zostały zignorowane przez prowadzących śledztwo — tego mężczyzny nigdy nie przesłuchano, a matkę nadal uznawano za zabójczynię i dwa miesiące później okazano jej odnalezione szczątki dziewczyny rzekomo celem rozpoznania, w rzeczywistości była to próba nakłonienia jej do przyznania się (już wcześniej medyk sądowy zidentyfikował zwłoki na podstawie uzębienia).

Sprawca zabójstwa został wykryty przypadkowo (rozpoznany przez ofiarę zgwałcenia) po czternastu miesiącach od zaginięcia dziewczyny. Był badany przy użyciu poligrafu, zapisy jego parametrów fizjologicznych w teście Reida były wręcz przeciwieństwem zapisów matki.

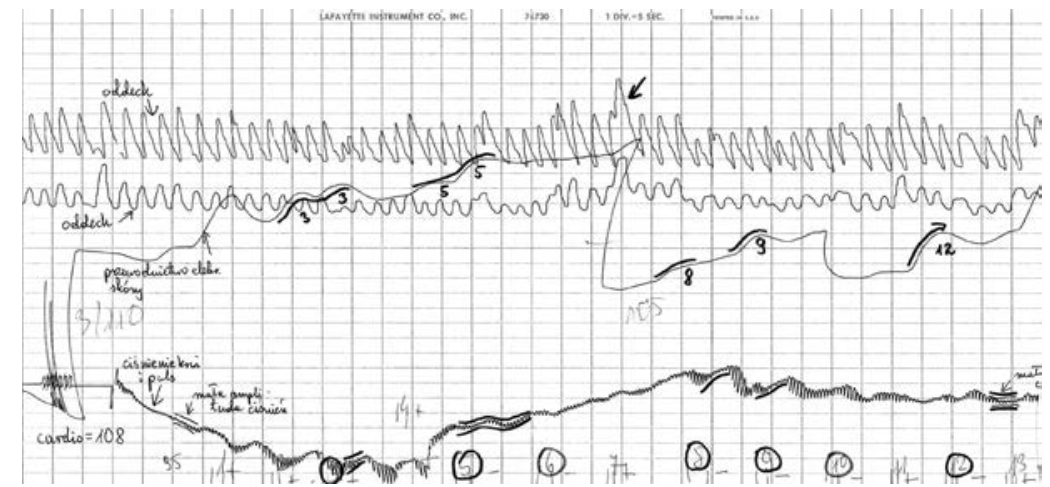

Il. 3. Zapis testu pytań kontrolnych z podejrzanym, który był rzeczywistym zabójcą dziewczyny.

Źródło: materiały własne autora.

Przyznał się później i powiedział, że dziewczynę zaatakował przypadkowo (ślady potwierdzały taki przebieg zdarzenia), został skazany na jedenaście lat pozbawienia wolności ${ }^{18}$.

18 Przyczyną lekceważenia ekspertyzy poligraficznej może być radykalna reorganizacja prokuratury i policji, jaka dokonywała się w tym czasie; ekspertyzę zarządził prokurator wojewódzki i czynności śledcze wykonywali policjanci z komendy wojewódz- 


\section{Przypadek 6}

Śledztwo prowadzone przez prokuraturę rejonową w Wieluniu dotyczyło zaginięcia ośmioletniej dziewczynki w czerwcu 2002 roku. Podejrzewano ojca o uprowadzenie i ukrycie córki, przedstawiono mu taki zarzut i aresztowano ${ }^{19}$. Istniało kilka poszlak obciążających ojca, głównie zeznania świadka twierdzącego, że widział, jak ojciec dziecka zabrał je samochodem z okolic szkoły. Prokurator przedstawił ojcu zarzut uprowadzenia córki, a sąd zastosował areszt. Po paru miesiącach areszt uchylono, ale mężczyzna nadal był osobą podejrzaną.

Podstawowa hipoteza była znacznie poważniejsza, gdyż dotyczyła molestowania seksualnego córki przez ojca. Przypuszczano, że obawa przed ujawnieniem tych faktów przez dziecko skłoniła ojca do zabójstwa. Taki motyw sugerowała lokalna społeczność i rozwijały środki masowego przekazu.

Badania ojca, matki i świadka przeprowadziłem pięć miesięcy po zdarzeniu. Trzeba dodać, że ekspertyza została wykonana w czasie, gdy dopuszczalność tej metody badawczej była kontestowana ${ }^{20}$, a prokurator generalny zabronił wręcz prokuratorom korzystania z niej ${ }^{21}$. Prokurator zdecydował się złamać ten zakaz, co okazało się trafną decyzją i przyniosło przełom w śledztwie: ekspertyza poligraficzna oczyściła niewinnego ojca, a pomogła w zdemaskowaniu zabójcy, który jako świadek przez parę miesięcy swoimi fałszywymi informacjami praktycznie sterował śledztwem.

Ojciec dziewczynki był przekonany, że córka żyje i zostanie odnaleziona, a porwał ją jakiś pedofil, aby grała w filmie pornograficznym.

kiej, a miesiąc później śledztwo przejęli policjanci i prokurator ze szczebla rejonowego. W tym czasie z pracy odeszło wielu doświadczonych policjantów i prokuratorów.

19 Ibidem, s. 259-286.

20 Por. A. Gaberle, $W$ kwestii badań poligraficznych $w$ polskim procesie karnym, „Państwo i Prawo” 2002, nr 4, s. 19-30; B. Bieńkowska, Nowy kodeks postępowania karnego, [w:] Nowe uregulowania prawne w kpk z 1997 r., red. P. Kruszyński, Warszawa 1999, s. 50.

21 Art. 171 k.p.k. zabraniający stosowania urządzeń rejestrujących nieświadome reakcje organizmu interpretowano jako zakaz używania poligrafu. Por. R. Jaworski, Ocena unormowań kpk z 1997 r. wobec badań poligraficznych na tle aktualnych form przestępczości, [w:] „Nowa Kodyfikacja Prawa Karnego” 5, 2000. 
Miał świadomość istniejących pogłosek odnośnie do molestowania i zabójstwa córki.

Pytania relewantne:

3. Czy wie pan, kto pozbawił życia Olę?

5. Czy to pan pozbawił życia Olę?

8. Czy wie pan, gdzie jest ciało Oli?

9. Czy zna pan osobę, która teraz opiekuje się Olą?

12. Czy wie pan, kto zabrał Olę spod szkoły?

Pytania kontrolne: 6 i 10.

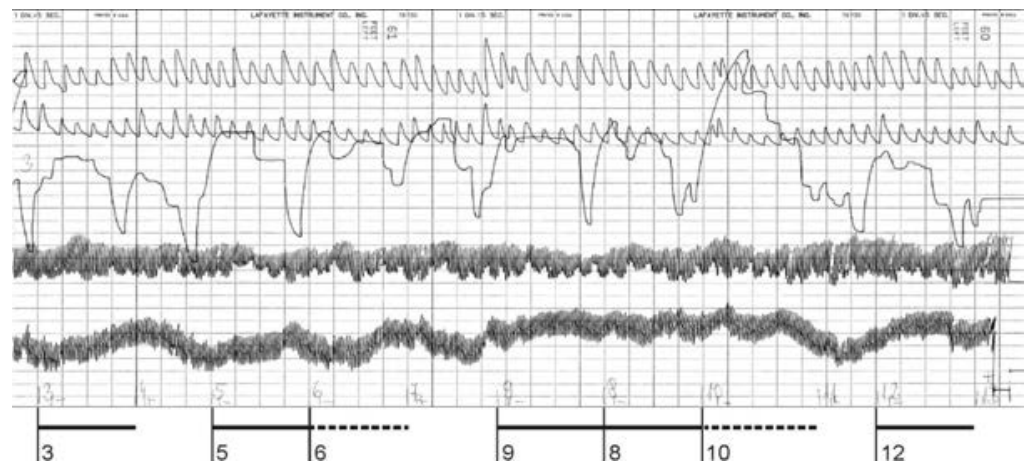

Il. 4. Drugi zapis testu zasadniczego z badania ojca zaginionej dziewczynki z reakcjami na najbardziej istotne pytania nr 5, 8 i 9. Pytania relewantne podkreślone są linią ciągłą, a kontrolne - linią przerywaną. Reakcja na pytanie relewantne nr 5 jest zdecydowanie mniejsza niż na kontrolne nr 6 (por. zapis cardio). Zwraca uwagę zdecydowanie silniejsza reakcja na pytanie kontrolne $\mathrm{nr} 10$ niż na wszystkie pytania relewantne.

Źródło: materiały własne autora.

Podobne proporcje w zapisie parametrów fizjologicznych wystąpiły w kolejnych dwóch zapisach testu. Dało to podstawę do wykluczenia obu hipotez dotyczących roli ojca w zaginięciu córki: zabójstwa i uprowadzenia (ukrycia).

Badania matki zaginionej początkowo wydały się niemożliwe z powodu silnych emocji, jednak te ustąpiły po dłuższym wywiadzie przedtestowym. W pytaniach relewantnych ujęta była tylko hipoteza ukrycia przez nią córki i obciążania męża fałszywymi zarzutami. Zarejestrowane $\mathrm{u}$ tej kobiety parametry fizjologiczne (pytania relewantne i pytania kontrolne) wykluczyły te hipotezy. 
Tego samego dnia był badany najważniejszy świadek w tej sprawie, który twierdził, że ojciec zabrał córkę spod szkoły po zakończeniu zajęć. Był to młody człowiek, kawaler, w wieku dwudziestu dwóch lat o niepełnym wykształceniu podstawowym. W wywiadzie wstępnym twierdził, iż stan jego zdrowia jest doskonały. W trzech zapisach testu pytań kontrolnych występowały u niego duże zmiany fizjologiczne, a najsilniejsze przy pytaniu „Czy wie pan, gdzie jest ciało Oli?” (były to tzw. bloki w zapisie oddechu trwające 10-20 sekund).

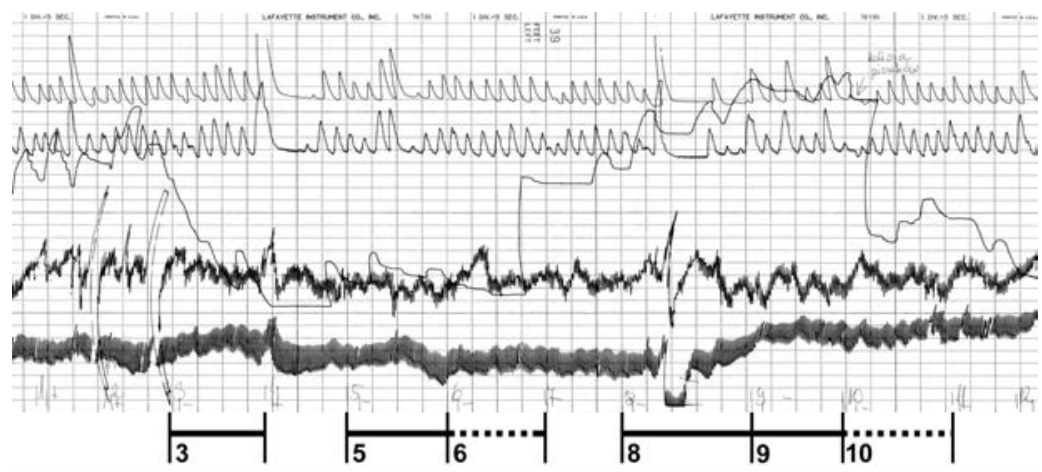

Il. 5. Pierwszy zapis testu zasadniczego z badania rzeczywistego zabójcy dziewczynki. Pytania relewantne podkreślone są linią ciągłą, a kontrolne - linią przerywaną. Badany najsilniej reagował na pytanie nr 8 (Czy ukryłeś gdzieś ciało?). Uwagę zwracają długotrwałe „bloki” w oddechu.

Źródło: materiały własne autora.

Człowiek ten wykazywał bardzo duże zmiany parametrów fizjologicznych w teście poszukiwawczym (wydobywczym) zmierzającym do ustalenia, co sprawca mógł zrobić z ciałem dziecka. Po tym teście oświadczył, że niedawno lekarz wykrył u niego poważną chorobę serca mogącą spowodować śmierć i odmówił dalszego udziału w badaniu. Człowiek ten przyznał się po czterech miesiącach od badania. Powiedział, że śmierć dziecka spowodował przypadkowo. Wyjaśnił, że ciało dziewczynki przez tydzień przechowywał kolejno w kilku miejscach, a następnie spalił w palenisku parnika. Został skazany na siedem lat pozbawienia wolności za nieumyślne spowodowanie śmierci dziecka i znieważenie zwłok. 


\section{Przypadek 7}

Zaginięcie młodego człowieka, do którego doszło w grudniu 2011 roku, było zagadkowe: pracował z ojcem przy naprawie ciężarówki, ojciec pojechał na zakupy, a gdy wrócił, nie zastał syna w warsztacie ${ }^{22}$. Syn musiał opuścić dom i warsztat w ubraniu i butach roboczych, nie zabrał żadnych dokumentów, samochodu ani pieniędzy. Przypuszczano, że albo poszedł gdzieś (dokonał samobójstwa), albo ktoś przyjechał samochodem i zabrał go (uprowadzenie i zabójstwo). Hipoteza prokuratury: mógł istnieć konflikt mężczyzny z ojcem na tle niedawnego rozwodu z matką oraz przyszłości syna (ojciec nalegał, aby pracował w warsztacie). Badanie poligraficzne wykluczyło, aby ojciec dokonał zabójstwa syna. Po upływie roku odnaleziono zwłoki zaginionego pod drzewem, ponad kilometr od domu. Ślady wskazywały na samobójstwo. Były one tam, gdzie wskazał jasnowidz K. Jackowski, ale nakreślony przez niego szkic należało odwrócić o 180 stopni. Ojciec mógł uważać, że jego zachowanie — żądanie, aby syn pracował w warsztacie — było właściwe.

\section{Wnioski}

Badania poligraficzne są bardzo przydatne do weryfikacji hipotezy o przyczynieniu się danej osoby do zabójstwa lub samobójstwa.

1) Testy CQT sprawdzają się nawet w sytuacjach ekstremalnie trudnych emocjonalnie dla osób badanych, a do takich niewątpliwie zaliczyć należy podejrzenie matki lub ojca o zabicie dziecka.

2) Testy poszukiwawcze podnoszą trafność opinii końcowej; przy ich powtarzaniu ekspert uzyskuje dodatkowe przesłanki diagnostyczne. Testy te powodują u sprawców wzrost pobudzenia emocjonalnego, zwłaszcza te dotyczące sposobów zniszczenia lub ukrycia ciała oraz lokalizacji geograficznej miejsc ukrycia. U niektórych jest ono tak duże, że skłania ich do przyznania się albo zachowań ewidentnie ujawniających ich udział w zabójstwie.

3) Testy takie dotyczyć mogą kilku problemów.

22 Prokuratura rejonowa w Częstochowie, sygnatura akt 3 Ds. 4/12. 
4) Przy badaniu członków rodziny problem ukrycia zwłok można zamaskować, redagując pytania dotyczące np. przedmiotu, który zaginiony miał z sobą lub części ubioru.

Rozważając aspekty moralno-etyczne badań poligraficznych w odniesieniu do poszukiwania zaginionych, konieczne jest uwzględnienie ich znaczenia także dla policjantów (i prokuratora, jeśli prowadzone jest postępowanie karne). Dążąc do wyjaśnienia sprawy, muszą oni opracować i sprawdzić różne wersje, także dotyczące przyczynienia się rodziny do „zniknięcia” człowieka. Czy próbowano zrozumieć sytuację policjanta lub prokuratora, który osoby najbliższe zaginionemu również musi traktować jako hipotetycznych zabójców, dokonywać wobec nich różnych czynności, niekiedy dla nich wysoce dolegliwych, przy pełnej świadomości, iż wersja taka może być błędna? A czy można tych czynności zaniechać, przyjmując np. założenie, iż matka lub ojciec własnego dziecka nigdy nie zabije? Badania poligraficzne, na tle innych, alternatywnie wykonywanych czynności, wydają się rozwiązaniem optymalnym, ponieważ ich dolegliwość dla badanych jest zdecydowanie najmniejsza, a wyniki uzyskiwane są szybciej.

\section{Bibliografia}

Bieńkowska B., Nowy kodeks postępowania karnego, [w:] Nowe uregulowania prawne w kpk z 1997 r., red. P. Kruszyński, Warszawa 1999.

Gaberle A., W kwestii badań poligraficznych w polskim procesie karnym, „Państwo i Prawo" 2002, nr 4, s. 19-30.

Jaworski R., Multi-subject Polygraph Examination, Wrocław 2008.

Jaworski R., Ocena unormowań kpk z $1997 \mathrm{r}$. wobec badań poligraficznych na tle aktualnych form przestępczości, „Nowa Kodyfikacja Prawa Karnego” 5, 2000.

Jaworski R., Personalization and calibration of the control question in the control question test, „Journal of Forensic Identification” 61, 2011, nr 5, s. 447-467.

Jaworski R., Poligraf jako narzędzie weryfikacji wersji zabójstwa, Wrocław 2018.

Jaworski R., Poligraficzny test ,wydobywczy” przy poszukiwaniu ciata ofiary zabójstwa, „Wrocławskie Studia Sądowe” 4, 2012, nr 3, s. 50-59.

Jaworski R., Praktyczne zastosowanie badań poligraficznych $i$ ich ocena etyczna, „Problemy Praworządności” 1989, nr 2, s. 43-56.

Johnston A., Saga o Leonardzie Keelerze, „Saturday Evening Post” kwiecień 1944, cyt. za: Academy Lectures on Lie-Detection, t. 2, Springfield 1958, s. 9-11.

Matte J.A., Forensic Psychophysiology Using the Polygraph. Scientific Truth Verification - Lie Detection, Willamsville-New York 1996. 
Nakayama M., Practical Use of the Concealed Information Test for Criminal Investigation in Japan, [w:] Handbook of Polygraph Testing, red. M. Kleiner, London 2002.

Saldziunas V., Kovalenko A., The event knowledge test (ekt) in polygraph examination (in case murder), „European Polygraph” 2, 2008, nr 2 (4), s. 139-144.

Wilkerson O.M., The peak of tension tests utilized in the Ashmore kidnapping, „Polygraph" 7, 1978, nr 1, s. 16-20.

\title{
Akty prawne
}

Prokuratura powiatowa w Oławie, sygnatura akt Ds. 70/79.

Prokuratura rejonowa w Częstochowie, sygnatura akt 3 Ds. 4/12.

Prokuratura rejonowa w Jeleniej Górze, sygnatura akt 1 Ds. 81/94/S.

Prokuratura rejonowa w Żarach 1978 Ds. 490/86.

Sąd Najwyższy, sygnatura akt II Kr 192/80.

Sąd wojewódzki we Wrocławiu, sygnatura akt III K 104/79.

Ustawa z dnia 6 kwietnia 1990 roku o Policji, Dz.U. 2019 poz. 2020.

Zarządzenie nr 124 Komendanta Głównego Policji z dnia 4 czerwca 2012 roku w sprawie prowadzenia przez Policję poszukiwania osoby zaginionej oraz postępowania w przypadku ujawnienia osoby o nieustalonej tożsamości lub znalezienia nieznanych zwłok oraz szczątków ludzkich, Dziennik Urzędowy Komendy Głównej Policji 2012, poz. 29.

Zarządzenie nr 48 Komendanta Głównego Policji z dnia 28 czerwca 2018 roku w sprawie prowadzenia przez Policję poszukiwania osoby zaginionej oraz postępowania w przypadku ujawnienia osoby o nieustalonej tożsamości lub znalezienia nieznanych zwłok oraz szczątków ludzkich, Dziennik Urzędowy Komendy Głównej Policji 2018, poz. 77.

\section{Verification of the murder version in cases of human disappearance}

\author{
Summary
}

In cases of human disappearance, sometimes facts appear indicating the possibility of causing his death and hiding the corpse. Such hypotheses are formulated not only by law enforcement authorities, but also by the local community, and the family is slandered in them, sometimes friends of the missing person. The study, based on examples from expert practice, showed the usefulness of the polygraph test to verify such personal versions, including the exclusion of wrongly suspected persons close to the missing person 
(father and mother). In the course of such a study, several research techniques can be used, which have been shown to increase the accuracy of the results and sometimes allow the killer to be exposed.

Keywords: disappearance, murder, polygraph, variograph, search for missing persons, suspect, innocent. 